\title{
Assessment of Climate Change Impact using Hydro-meteorological Indicators-Rainfall, Temperature and Runoff in Mazam River Watershed, India
}

\author{
Payal R. Makhasana* and Geeta S. Joshi \\ Civil Engineering Department, Faculty of Technology \& Engineering, The Maharaja Sayajiro University of \\ Baroda, Vadodara, India
}

\begin{abstract}
Changing climate has significant impact on the river hydrology and water resources. An assessment of the availability of water resources in the context of future requirement and expected impact of climate change and its variability is critical for relevant national and regional long-term development strategies and sustainable development. Changes in the climate have been assessed through assessing the Metrologic parameters such as daily maximum and minimum temperature of the month, daily average temperature, annual rainfall, monthly rainfall of the monsoon season, and maximum daily rainfall of the year, number of rainy days in the year and number of rainy days in each month of monsoon season. It is observed that the 1) Maximum daily temperature shows increasing trend in summer season (March to June) and shows reducing trend in winter season (October to February) in the study area. This is indicative of extreme weather in climate change/advance scenario. 2) The monthly rainfall trend shows increasing trend for the magnitude of annual rainfall shows increasing trend in the study area. 3) The number of rainy days in the monsoon season (June to October) shows reducing trend. Rainfall-Runoff regression analysis has been carried out for base line and advance/climate change scenario to investigate the impact of climate change on Water Resources. This study will be helpful to water resources planners and decision makers regarding the strategies to be followed in view of changing climate.
\end{abstract}

Keywords: Temperature analysis, Climate change scenario, Trend analysis, Rainfall-Runoff

\section{Introduction}

Climate Change', the most uttered environmental term of present time has been used to refer to the change in modern climate brought predominantly by human being actions. It is perhaps one of the most serious environmental issues that today's world population facing though the issue (Seacrest and Kuzelka, 2000). Climate change is an unavoidable challenge that society is dealing and will have to deal with over coming decades. For developing countries, the task seems difficult to deal with in prospect. Climate change is having serious impacts on the water systems through extreme flooding and droughts events. Declining rainfall has adverse effect on water resources, agricultural output, industrial output and economy. It is well realized that natural climate variability (e.g. decadal changes in circulation) and human induced (e.g. land cover and emissions of greenhouse gases) changes alter the rainfall patterns (Oza et al, 2014). These changes will have profound effects on water requirement of Horticulture crop. The climate affects the demand for water as well as the supply, availability and quality; Particularly, in arid and semi-arid regions of India say shortfalls in water supply (Kumar et al., 2013). Surface runoff varies by time and location, with about one-third of the precipitation that falls on land turning into runoff; the other two-thirds is evaporated, transpired, or infiltrated into the soil (Sitterson et al., 2017). Hydrologic conditions vary from region to region, even under the same climatic scenarios, the influence of climatic change will likely differ between localities (Raneesh, 2014). Therefore, to regionalize the hydrologic response under a changing climate the study is taken up "Assessment of Climate Change and its Impact on RainfallRunoff correlations in Mazam river watershed, India". 
In India, precipitation increase of approximately $20 \%$ and increase in heavy rainfall days during the summer monsoon period, and an increased inter annual variability (Bhaskaran et al, 1995). In the semi-arid region where temperature shows a larger increase in the wet months, a likely decrease in precipitation is projected, (Faramarzi et al, 2013). Most climate change projections for the region call for modest and seasonally variable increases in precipitation (5-10\%) in Mara River Basin of East Africa, (Mango et al, 2011). A Study of Change in Rainfall Pattern in Dhatarwadi Reservoir Catchment, Amreli, Gujarat was analyzed using Linear Regression Analysis by Solanki et al ,2014 which shows increas/ing trend. The seasonality index which is the measure of distribution of precipitation throughout the seasonal cycle is used to classify the different rainfall regime for Maharashtra is done by Guhathakurta and Saji, 2013 which shows the month of August has proved to be very good for the state of Maharashtra and in coastal areas, SI is greater than 1.2 indicating the extreme rainfall regime where almost all the rain occurs in one to two months. In India, studies by several authors have shown that there is increasing trend in surface temperature and no significant trend in rainfall and decreasing/increasing trends in rainfall (Oza and Kishtawal, 2014).

Temperature is a very important factor in determining the weather, because it influences or controls other elements of the weather, such as precipitation, humidity, clouds and atmospheric pressure (Balasubramanian, 2017). The rate of increase was highest in June, July and August. Over the same period, the average number of cold days and nights decreased by 21 (5.8\% of days) and $41(11.2 \%$ of nights), respectively (Mamuye, 2013). In Asia, it is estimated that the mean continental surface temperatures increased by approximately $0.7^{\circ} \mathrm{c}$ over the 20th century and a further warming of $0.2-$ $0.5^{\circ} \mathrm{C}$ per decade is predicted for 2070-2100 (Raneesh, 2014). Many researches have been conducted during the last century to address the modeling of the relation between rainfall and runoff. To simulate this relation in a hydrological catchment two essential issues have to be investigated, the hydrological knowledge of the catchment and the observed data (Boulariah et al, 2017).

\section{Study Area and Data Collection}

Sabarmati river basin is one of the water scarce basins in India and is part of a fragile ecosystem that affects the country as well. It supports a population of nearly one crore people, 50 per cent of which is urban. Besides, it has a fairly developed agriculture and quite a large number of industries are also situated in the basin (Donkor and Wolde, 2001). Thus it is very important to assess the impact of climate change in the form of rainfall-runoff response, to find the potential of the runoff. In this study change in rainfall, intensity of rainfall, potential of runoff and also change in temperature have been investigated for the Mazam river watershed. Mazam is a tributary of river Watrak which is one of the major rivers flowing in Sabarmati Basin. Figure 1 shows index map of India with delineation of watershed using Arc- GIS for Sabarmati basin with Mazam river watershed. 


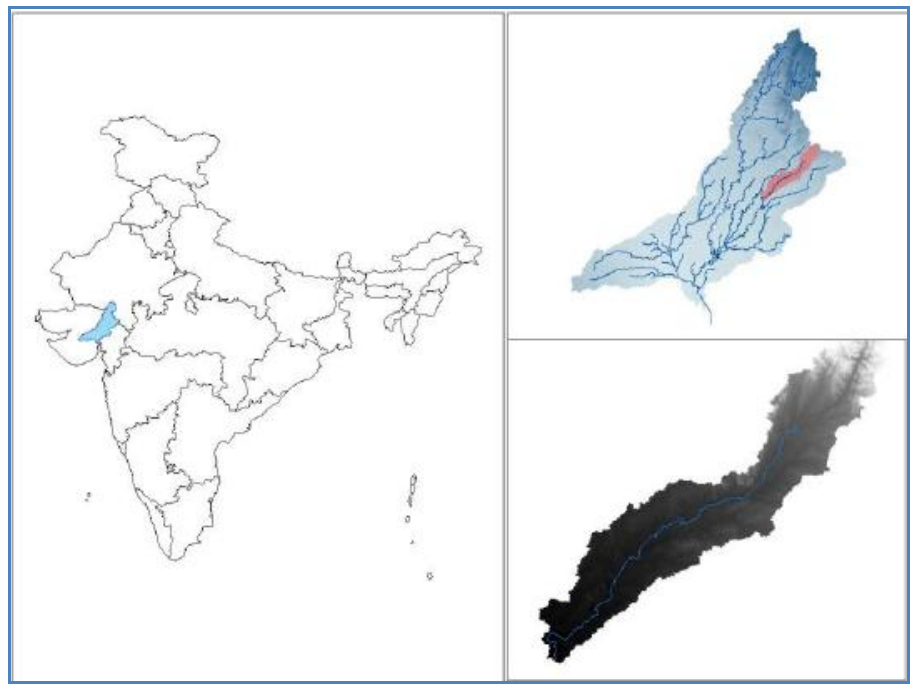

Figure 1 Index map of India with Sabarmati Basin and Mazam River watershed delineated in Arc-GIS

Mazam River is a tributary of Watrak River basin which is one of the major Rivers rested in the Sabarmati basin and having length of $78.85 \mathrm{~km}$ and passes from Meghraj, Sabarkantha and Modasa district. Mazam dam have been constructed on the Mazam River for an irrigation project with area of Catchment $955.98 \mathrm{~km}^{2}$. There are two rain gauging station, namely Rellawada and Vadagam have been installed in the study area and data available from 1961 to 2016 from State water Data Center (SWDC). There is one river gauging station Ambaliyara, having catchment area 955.98 square $\mathrm{km}$ and discharge data available from the 1981 to 2016 from SWDC. The average annual rainfall at the station Rellawada and Vadagam is found to be $735 \mathrm{~mm}$ and $727.24 \mathrm{~mm}$ respectively. These Stations are found sufficient as the adequate stations, even with $4 \%$ error in mean rainfall. There are also two weather stations namely, Modasa and Ambaliyara in this study area and data are available from the 2000 to 2015 from SWDC. Figure 2 shows all these station in study area.

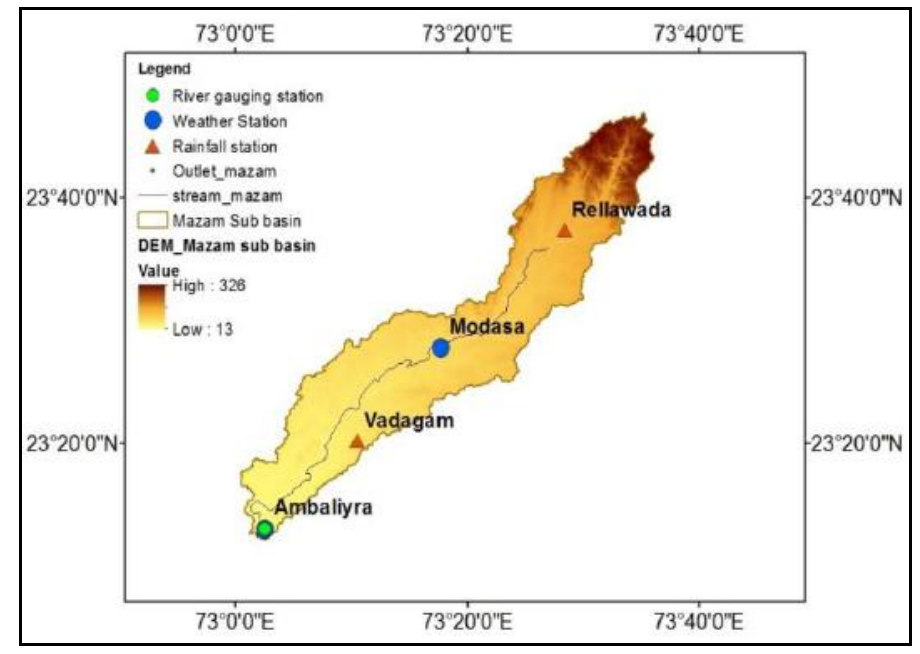

Figure 2 Mazam river watershed with river gauge, rainfall and weather stations 


\section{Data Analysis and Methods \\ Mann-Kendall trend test}

Trend analysis is carried out using non-parametric Man- Kendall test which is a statistical method formulated by Mann (1945) as non-parametric test for trend detection and the test statistic distribution had been given by Kendall (1975) for testing non-linear trend. Mann-Kendall (MK) Test, Modified Mann-Kendall Test have been used together with the Sen's Slope Estimator for the determination of trend and slope magnitude by Mondal et al, 2012 and Kuma et al, 2010. The Mann-Kendall test statistic is computed as

$$
\mathrm{S}=\sum_{j=1}^{n-1} \sum_{j=1+i}^{n} \operatorname{sgn}\left(x_{j}-x_{i}\right)
$$

The application of trend test is demonstrated to a time series that is ranked from $i=1,2, \ldots \ldots \ldots, n-$ 1 and , which is ranked from $\mathrm{j}=\mathrm{i}+1,2, \ldots \ldots \ldots . . \mathrm{n}$. Each of the data point is taken as a reference point which is compared with the rest of the data points so that,

$$
\operatorname{sgn}\left(x_{j}-x_{i}\right)=\left\{\begin{array}{c}
+1_{s}>\left(x_{j}-x_{i}\right) \\
0=\left(x_{j}-x_{i}\right) \\
-1,<\left(x_{j}-x_{i}\right)
\end{array}\right.
$$

It has been documented that when $\mathrm{n} \geq 8$, the statistic $\mathrm{S}$ is approximately normally distributed with the mean. $\mathrm{E}(\mathrm{S})=0$

The variance statistic is given as

$$
\operatorname{Var}(S)=\frac{n(n-1)(2 n+5)-\sum_{i=1}^{n} t_{i}(i)(i-1)(2 i+5)}{18}
$$

Where ti is considered as the number of ties up to sample $\mathrm{i}$. The test statistics $\mathrm{Zc}$ is computed as

$$
Z_{c}=\left\{\begin{array}{l}
\frac{s-1}{\sqrt{\operatorname{Var}(S)}}, S>0 \\
0, S=0 \\
\frac{S+1}{\sqrt{\operatorname{Var}(S)}}, S<0
\end{array}\right.
$$

$\mathrm{Zc}$ here follows a standard normal distribution. A positive (negative) value of $\mathrm{Z}$ signifies an upward (downward) trend. A significance level $\alpha$ is also utilized for testing either an upward or downward monotone trend (a two-tailed test). If Zc appears greater than $Z \alpha / 2$ where $\alpha$ depicts the significance level, then the trend is considered as significant (Mondal et al, 2012). Here significant level is considered as 0.05 . The Mann-Kendall statistical test has been frequently used to quantify the significance of trends in hydro-meteorological time series by Gocic, M. and Trajkovic, S. (2013).

\section{Sen's Slope Estimator Test:}

The magnitude of trend is predicted by the Sen's estimator. Here, the slope (Ti) of all data pairs is computed as (Sen, 1968) 
$T_{i}=\frac{x_{j}-x_{k}}{j-k}$ for $\mathrm{i}=1,2 \ldots \ldots \ldots . \mathrm{N}$

Where $x_{j}$ and $x_{k}$ are considered as data values at time $\mathrm{j}$ and $\mathrm{k}(\mathrm{j}>\mathrm{k})$ correspondingly.

If there is only one datum in each time period, then $\mathrm{N}=\frac{n(n-1)}{2}$; where $\mathrm{n}$ is the number of time periods. If there are multiple observations in one or more time periods, then $\mathrm{N}=\frac{n(n-1)}{2}$; where $\mathrm{n}$ is the total number of observations. The median of these $N$ values of $T_{\hat{i}}$ is represented as Sen's estimator of slope which is given as:

$\mathrm{Q}_{\mathrm{i}}=\left\{\begin{array}{c}\mathrm{T}_{\frac{\mathrm{N}+1}{2}}, \mathrm{~N} \text { is odd } \\ \frac{1}{2}\left(\frac{\mathrm{T}_{\mathrm{N}}}{2}+\frac{\mathrm{T}_{\mathrm{N}+2}}{2}\right), \mathrm{N} \text { is even }\end{array}\right.$

Sen's estimator is computed as $Q_{m e d}=T_{\frac{\mathrm{N}+1}{2}}$ if $\mathrm{N}$ appears odd, and it is considered as $Q_{\text {med }}=\frac{1}{2}\left(T_{\frac{\mathrm{v}}{2}}+T_{\frac{\mathrm{w}+2}{2}}\right)$ if $\mathrm{N}$ appears even. At the end, $Q_{\text {med }}$ is computed by two sided test at $100(1-\alpha)$ $\%$ confidence interval and then a true slope can be obtained by the non-parametric test. Positive value of Qi indicates an upward or increasing trend and a negative value of Qi gives a downward or decreasing trend in the time series (Önöz, B. and Bayazit, M. , 2003) .Lacombe, G. and McCartney, M. (2016) and Lee, S. et al. (2018) use this method for detection of magnitude of slope and to find magnitude of trend line. Mann-Kendall test have been carried out to identify the trend of annual rainfall and monthly at all four rain gauging stations of the basin and the results are shown in Table 2 .

\section{Changes in Magnitude of Trend}

The change percentage has been computed by approximating it with a linear trend, which is calculated as the median slope (Sen's slope) multiplied by the period length divided by the corresponding mean, expressed as percentage.

Percentage Change $(\%)=\left(T_{\mathrm{i}} \times\right.$ length of year $) /$ mean $\times 100$

\section{Analysis of monthly Rainfall with Rainy Days}

Monthly rainfall analysis and annual rainfall analysis of rainfall with number of rainy days and the trends have been detected using linear regression technique as $\mathrm{Y}=\mathrm{mx}+\mathrm{C}$. Where, $\mathrm{y}$ is the observation on the dependent variable (ex. Annual rainfall), $\mathrm{x}$ is the observation on the independent variable (ex. Year), $\mathrm{m}$ is the slope of the line and $\mathrm{C}$ is an intercept of the vertical axis. The annual 
rainfall data series along with number of rainy days of the year at the Vadagam station is shown in Figure 3. Maximum rainfall in a day at station Vadagam is shows in Figure 4. Same as monthly rainfall data series along with number of rainy days are also analyzed.

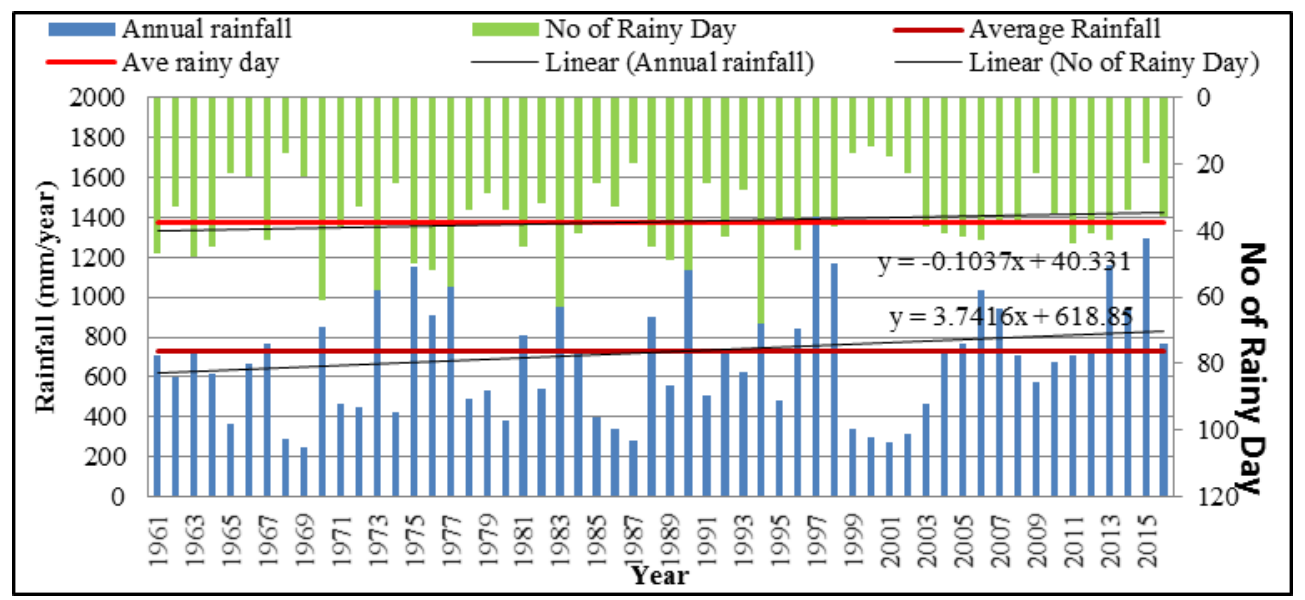

Figure 3 Trend of analysis of annual rainfall and number of rainy day in that year at Vadagam station

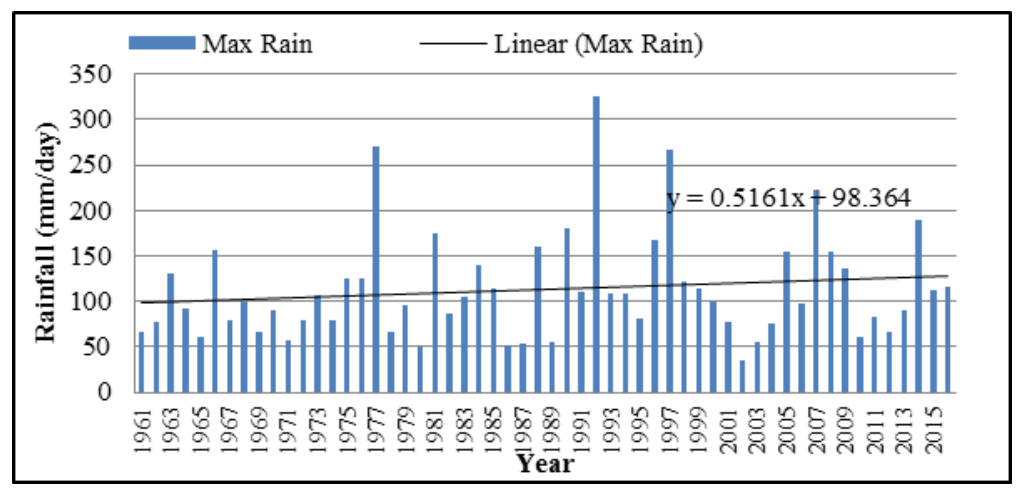

Figure 4 Maximum rainfalls per day in the year at the Vadagam station

From the above figure it shows that with increases in annual rainfall number of rainy days does a not increase perceptible and maximum rainfall per days shows increasing trend that verified that intense rainfall occurs as compare to earlier years. Results of all the station and for all the months are mention in Table 1.

\section{Analysis of Range of the daily Rainfall for monsoon month}

With increase in the monthly rainfall, the corresponding increase in number of rainy day is not noticeable from Figure 3 and also maximum rainfall in year shows increasing trend. It is verified from the above figures directly that with change in rainfall pattern due to climate change it is necessary to find trend of the daily rainfall of the months in various ranges with changing climate. Numbers of day with different range that given by IMD in mm/day of the July month at Vadagam station is shows in Figure 5 to 6. 


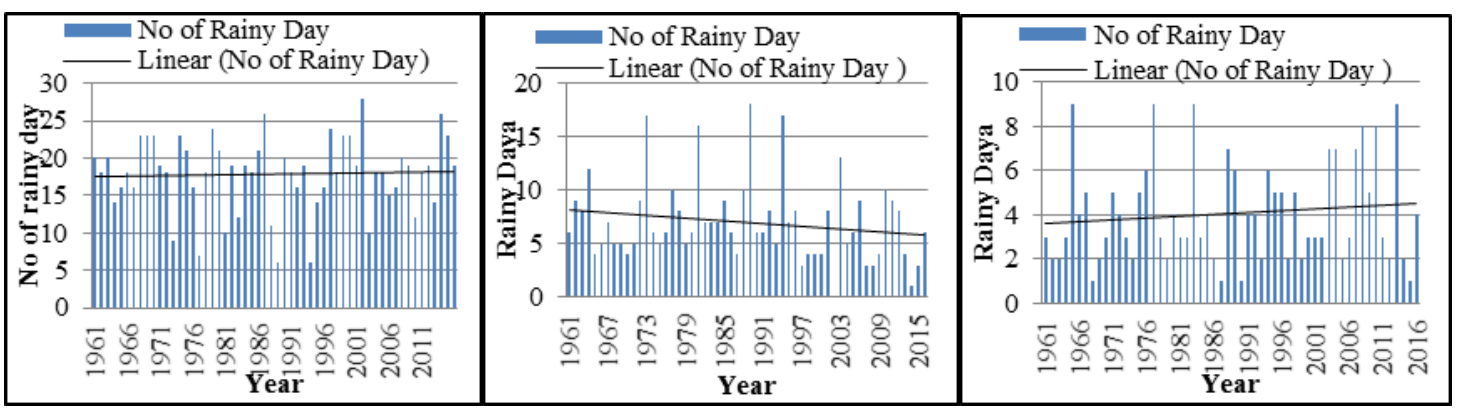

Figure 5 Numbers of day with $0 \mathrm{~mm}$ rainfall/day, 0.1 to $10 \mathrm{~mm}$ rainfall/day, and 10.1 to $35.5 \mathrm{~mm}$ rainfall/day at Vadagam station of month of July
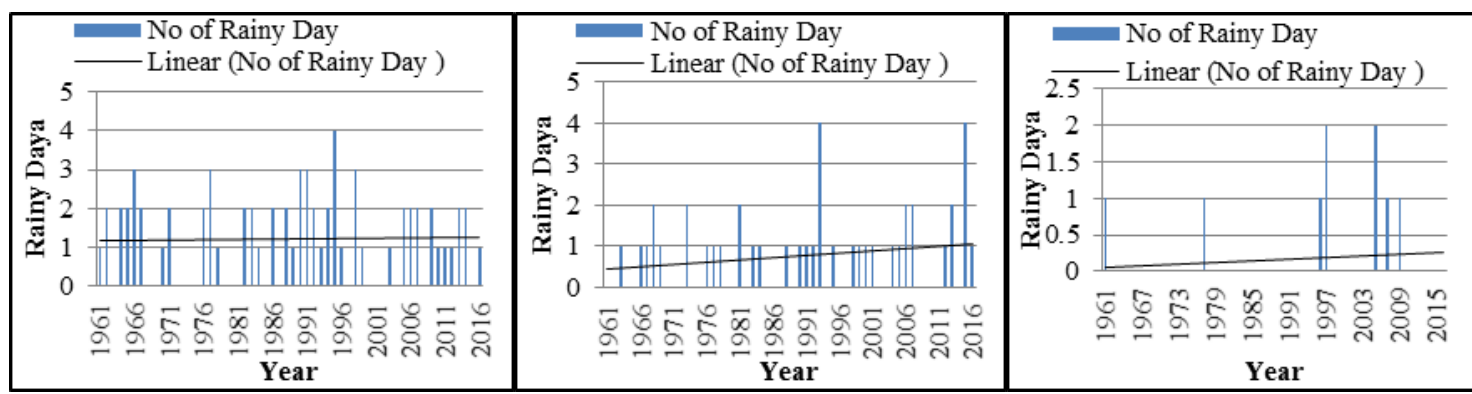

Figure 6 Numbers of day with 35.6 to $64.4 \mathrm{~mm}$ rainfall/day, 64.4 to $124.4 \mathrm{~mm}$ rainfall/day and above $124.4 \mathrm{~mm}$ rainfall/day at Vadagam station in month of July

Rainy days in month of July month shows decreasing day and rainfall with higher intensity in $\mathrm{mm}$ /day shows increasing trend, results for all the months and for both the stations are mention in Table 2.

\section{\% Changes in monsoon season annual rainfall in Base scenario and Advance scenario as a function of Cumulative frequency.}

\% Changes in annual rainfall in Base scenario and Advance scenario at the Mazam watershed basin from all rain gauging station as a function of Cumulative frequency have been developed and shows positive changes for most of the frequency values as shown in Figure 7. That is indicative of increasing trend of the annual rainfall in the Mazam river watershed.

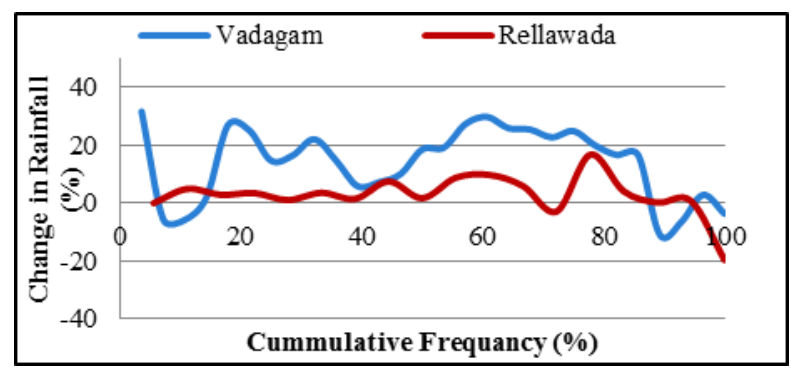

Figure 7 Changes in monsoon season annual rainfall in Base scenario and Advance scenario as a function of Cumulative frequency. 


\section{Analysis of Recurrence interval for rainfall magnitude in baseline and advance scenario}

The recurrence interval and frequency of a storm for various magnitude of annual rainfall, at each rain gauging station have been prepared for base line scenario and advanced scenario. The base line scenario is considered as the earlier half time-span (years) of the total data length, while the advanced scenario is considered as the latter half time -span (years). It is apparent from Figure 8 that the impact of climate change will more in the advanced scenario in comparison to the base line scenario. Similar results are also obtained for other stations in the basin.

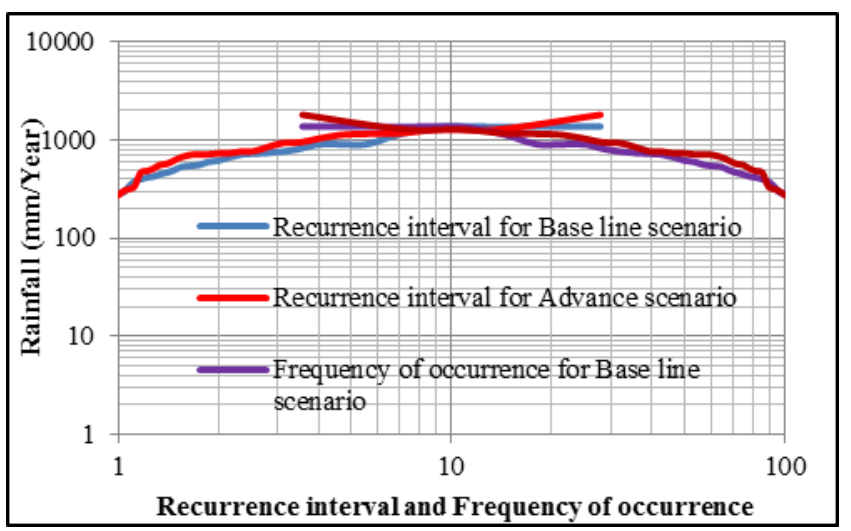

Figure 8 Recurrence Interval and Frequency of annual rainfall for station Vadagam

\section{Analysis of annual Rainfall-Runoff pattern}

The average annual rainfall over the study area has been computed using rainfall data of Vadagam and Rellawada station. The discharge data at Ambaliyara station is available since 1981 from State Water Data Centre (SWDC). As, the inflows data are available from year 1981, the annual rainfall (average) - inflows (measured at Ambaliyara station) has been represented from 1981 and is as shown in Figure 9 which shows that increase in annual rainfall, runoff decreases.

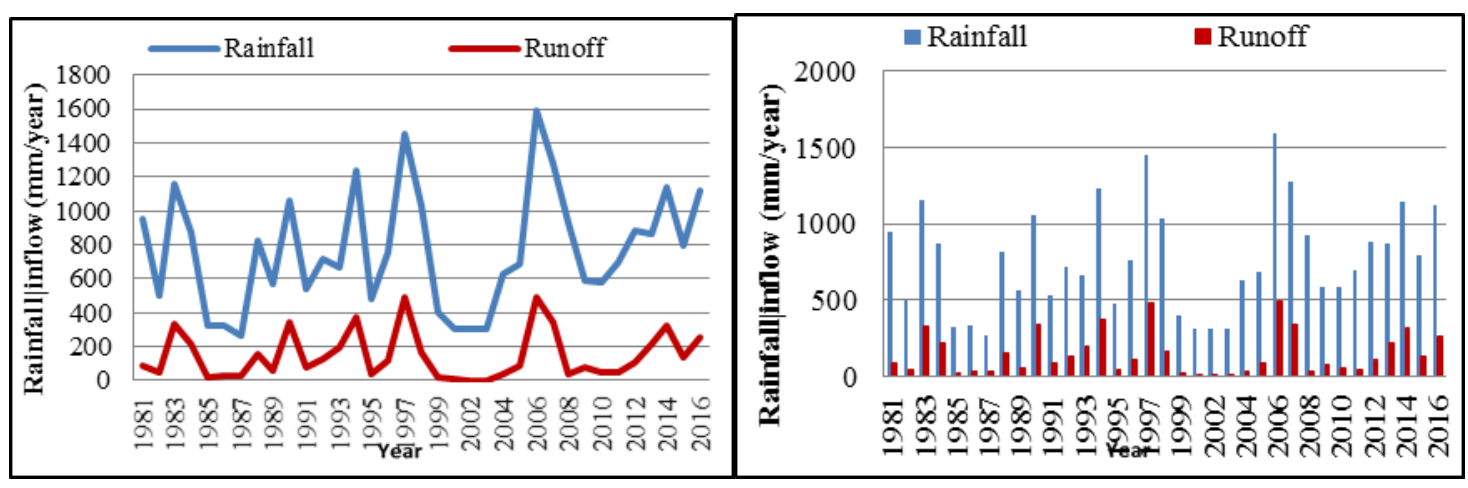

Figure 9 Annual rainfall and Inflow representation for Mazam river watershed for station Ambaliyara 


\section{Analysis of Rainfall-Runoff correlation trend in baseline and advance scenario for station Ambaliyara:}

Figure 9 represents annual rainfall and annual inflow, in the advance scenario, which can be considered as a later half time - span of the rainfall data series; and also for base line scenario, which can be considered for earlier half time-span of the rainfall data length. The rainfall- runoff correlations have been plotted for base line scenario and advance scenario separately and shown in Figure 10.

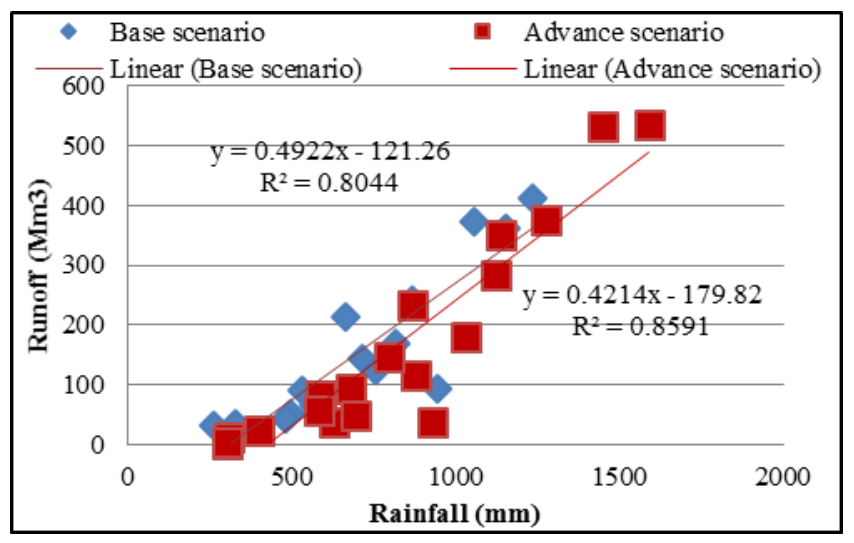

Figure 10 Annual rainfall-Runoff correlations for base line scenario and Advance scenario at Ambaliyara

Equation 8 represents the rainfall-runoff linear correlation for base line scenario.

$$
\mathrm{R}=0.4922 \mathrm{P}-121.26
$$

Where,

$\mathrm{R}=$ Annual Runoff/Inflows $(\mathrm{mm})$ at station Ambaliyara in base line scenario

$\mathrm{P}=$ Average annual rainfall $(\mathrm{mm})$ in the catchment area of Ambaliyara in base line scenario

Correlation coefficient between annual rainfall and runoff for base scenario has been found to be 0.8044 .

For advance scenario, the results of rainfall-Runoff correlations are expresses as in the equation (9), as shown in Figure 10.

$$
\mathrm{R}=0.4214 \mathrm{P}-179.82
$$

Where,

$\mathrm{R}=$ Annual Runoff/Inflows (mm) at station Ambaliyara in advance line scenario

$\mathrm{P}=$ Average annual rainfall $(\mathrm{mm})$ in the catchment area of Ambaliyara in advance line scenario

Correlation coefficient between annual rainfall and runoff for advance scenario has been found to be 0.8591 
It is observed from Figure 10, the runoff potential in advance scenario for entire range of rainfall from low to high is decreasing, meanwhile coefficient of correlation is higher as compare with the base scenario.

\section{Temperature Analysis}

There are two weather stations namely Ambaliyara and Modasa in this study area. The daily weather data at stations are available from 2001 to 2015, from State Water Data Centre (SWDC). Analyses of change in maximum-minimum temperature have been carried. Analyses of numbers of days that exceed average temperature of the month have been also carried out at these stations. The maximum temperature in the basin varies from $39^{\circ} \mathrm{C}$ to $46^{\circ} \mathrm{C}$. The average temperature of winter season months is $10^{\circ} \mathrm{C}-15^{\circ} \mathrm{C}$ in winters and as high as $38-46^{\circ} \mathrm{C}$ in summers. Figure 11 shows the minimum temperature of the day for the month January at Ambaliyara station. Figure 12 shows the maximum temperature and Trend of the number of days above having temperature greater the mean temperature of the month of January. The results of the these temperature analysis at both weather stations are shown in Table 3.

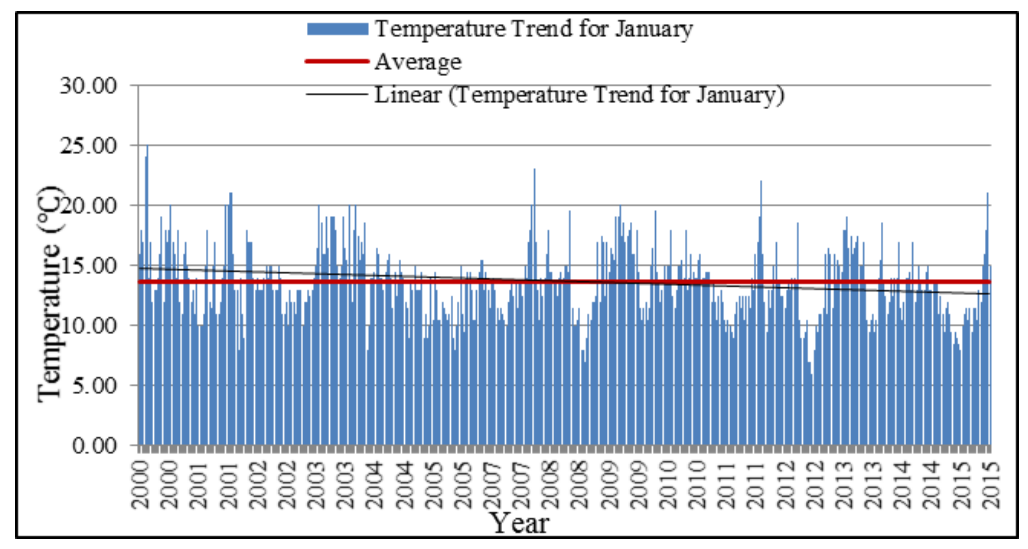

Figure 11 Minimum temperatures Trend at Amabaliyara station for month of January month.
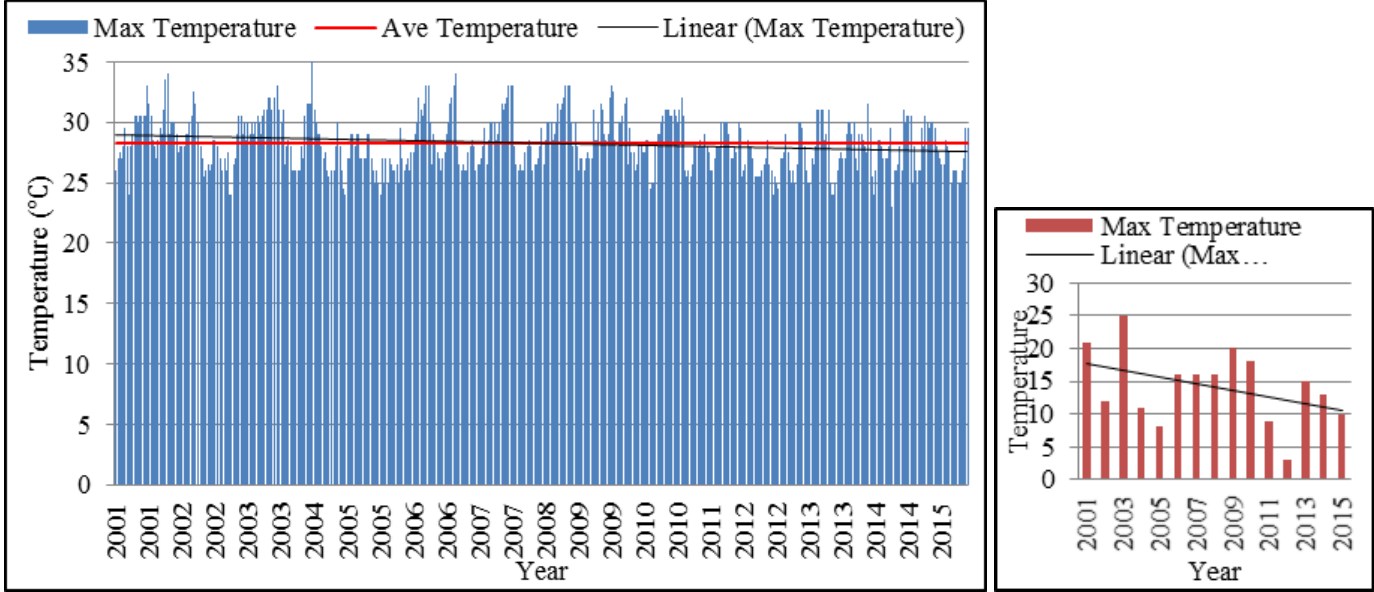

Figure 12 Maximum temperature trend and numbers of day above the average temperature at Ambaliyara station for January month. 


\section{Land-Use Change and land cover}

The distribution of land use/land cover in Mazam river basin for the year 1980 and for the year 2016 have been generated through supervised classification in Arc- GIS. For this purpose, the Landsat-8 OLI/TIRS C1 Level 2 images for year 2016 (advance scenario) have been used; and for year 1980 (base scenario), images are taken from Landsat-4-5 TM C1 Level 1 have been used through web link https://earthexplorer.usgs.gov/ . Land use Land cover distribution of the Mazam river basin for base scenario (1980) and advance scenario (2016) is shown in Figure 13. It is seen from Figure 13 that major part of the basin is covered with pasture land and agriculture land in advance scenario. Barren land and urban increases in advance scenario as compare with the base scenario. Table 1 shows the $\%$ area falling in each class of land use and land cover.

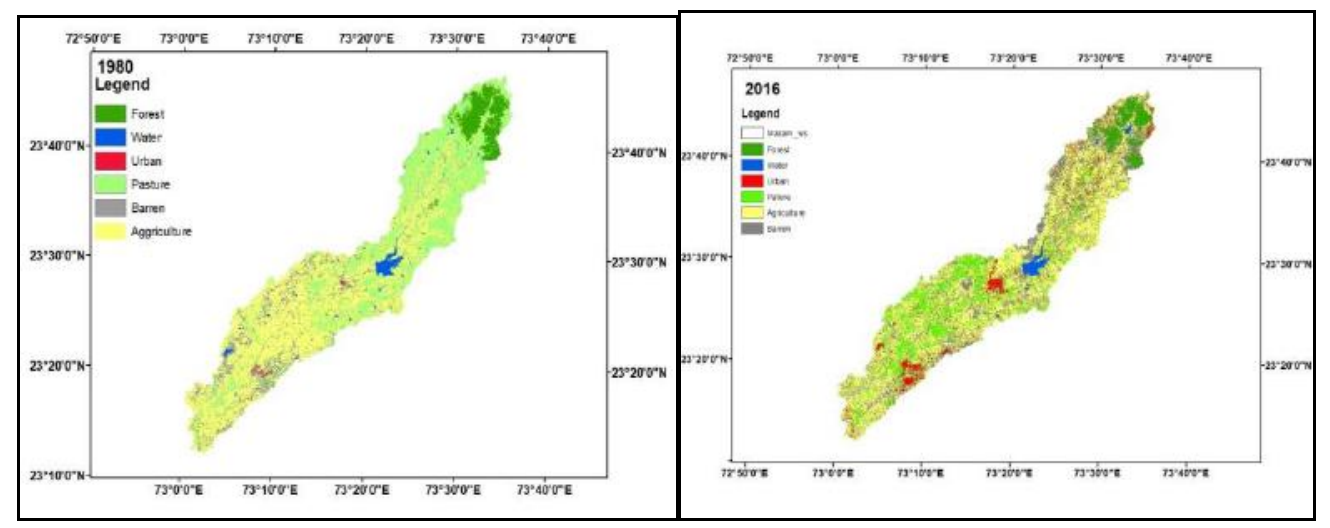

Fig 13 LULC map of Mazam river basin for year 1980 and 2016

Table 1 Change in LULC pattern in base scenario and Advance scenario

\begin{tabular}{cccc}
\hline $\begin{array}{c}\text { Object } \\
\text { ID }\end{array}$ & Class & \multicolumn{2}{c}{ \% Area } \\
\hline & & 1980 & 2016 \\
\hline 1 & Water & 1.74 & 1.96 \\
\hline 2 & Forest & 6.73 & 3.57 \\
\hline 3 & Agriculture & 45.02 & 32.48 \\
\hline 4 & Barren & 8.76 & 23.67 \\
\hline 5 & Pasture & 37.05 & 33.88 \\
\hline 6 & Urban & 0.72 & 4.43 \\
\hline
\end{tabular}

\section{Results}

1. Result of annual/monthly rainfall analysis and rainy day by graphical method and its verification is done by Mann-Kendal test statistics are mention in Table 2. It is seen from Table 2 that results from both the methods are matching. 
Payal R. Makhasana and Geeta S. Joshi / Assessment of Climate Change Impact.....

Table 2 Results of trend analysis of annual and monthly rainfall and its verification by Mann-Kendall test

\begin{tabular}{ccccccccc}
\hline Station & $\begin{array}{c}\text { Month/ } \\
\text { Annual }\end{array}$ & S & Zc & $\begin{array}{c}\text { Sen } \\
\text { slope }\end{array}$ & $\begin{array}{c}\text { Mean } \\
\text { Rainfall }\end{array}$ & $\begin{array}{c}\text { \% Change } \\
\text { in } \\
\text { Magnitude }\end{array}$ & $\begin{array}{c}\text { Rainfall } \\
\text { trend }\end{array}$ & Rainy Day \\
\hline \multirow{2}{*}{ Rellawada } & Annual & 96 & 1.2939 & 8.0454 & 735 & 39.41 & Increasing & Increasing \\
\cline { 2 - 9 } & June & 52 & 0.6965 & 0.4365 & 65.61 & 23.95 & Increasing & Decreasing \\
\cline { 2 - 9 } & July & 71 & 0.9535 & 2.6166 & 287.5 & 32.76 & Increasing & Decreasing \\
\cline { 2 - 9 } & August & 34 & 0.4495 & 1.0212 & 251.6 & 14.61 & Increasing & Increasing \\
\cline { 2 - 9 } & September & 117 & 1.5814 & 1.909 & 118.5 & 57.99 & Increasing & Increasing \\
\hline \multirow{2}{*}{ October } & 15 & 0.2348 & 0 & 12 & 0 & Increasing & Increasing \\
\cline { 2 - 9 } & Annual & 175 & 1.2297 & 2.5455 & 727.24 & 19.60 & Increasing & Increasing \\
\cline { 2 - 9 } & June & -45 & -0.312 & 0 & 71.65 & 0 & Decreasing & Decreasing \\
\cline { 2 - 9 } & July & 174 & 1.2226 & 1.5269 & 266.15 & 32.13 & Increasing & Decreasing \\
\cline { 2 - 9 } & August & 66 & 0.4594 & 0.7169 & 232.77 & 17.25 & Increasing & Decreasing \\
\cline { 2 - 9 } & September & 5 & 0.0283 & 0 & 120.6 & 0 & Increasing & Increasing \\
\cline { 2 - 9 } & October & 102 & 0.8645 & 0 & 22.48 & 0 & Increasing & Increasing \\
\hline
\end{tabular}

2. Trend of daily rainfall depth in different ranges that given by IMD in $\mathrm{mm} /$ day are mention in Table 3 and its shows different range of heavy rainfall shows increasing trend in month of July and September only while moderate rainfall increases in all the month

Table 3 Results of daily rainfall depth in different ranges that given by IMD

\begin{tabular}{|c|c|c|c|c|c|c|c|}
\hline & & No rainfall & $\begin{array}{l}\text { Light } \\
\text { rainfall }\end{array}$ & $\begin{array}{l}\text { Moderate } \\
\text { rainfall }\end{array}$ & $\begin{array}{l}\text { Rather } \\
\text { heavy } \\
\text { rainfall }\end{array}$ & $\begin{array}{l}\text { Heavy } \\
\text { rainfall }\end{array}$ & $\begin{array}{l}\text { Very } \\
\text { heavy } \\
\text { rainfall }\end{array}$ \\
\hline Station & Month & $0 \mathrm{~mm}$ & $\begin{array}{l}0.1 \text { to } 10 \\
\mathrm{~mm}\end{array}$ & $\begin{array}{l}10.1 \text { to } \\
35.5 \mathrm{~mm}\end{array}$ & $\begin{array}{l}35.6 \text { to } \\
64.4 \mathrm{~mm}\end{array}$ & $\begin{array}{l}64.5 \text { to } \\
124 \mathrm{~mm}\end{array}$ & $>124 \mathrm{~mm}$ \\
\hline \multirow[t]{5}{*}{ Rellawada } & June & Increasing & Increasing & Increasing & Increasing & Increasing & Increasing \\
\hline & July & Decreasing & Increasing & Increasing & Increasing & Increasing & Increasing \\
\hline & August & Decreasing & Increasing & - & Increasing & - & Decreasing \\
\hline & September & Decreasing & Increasing & Increasing & Increasing & Increasing & Increasing \\
\hline & October & Decreasing & Increasing & Increasing & Decreasing & Increasing & - \\
\hline \multirow[t]{5}{*}{ Vadagam } & June & Increasing & Decreasing & Increasing & Decreasing & Increasing & Increasing \\
\hline & July & Increasing & Decreasing & Increasing & Increasing & Increasing & Increasing \\
\hline & August & Increasing & Decreasing & Increasing & Increasing & Decreasing & Decreasing \\
\hline & September & Decreasing & Increasing & Increasing & Increasing & Increasing & Increasing \\
\hline & October & Decreasing & Increasing & - & Decreasing & Decreasing & - \\
\hline
\end{tabular}


3. \% Changes in annual rainfall in Base scenario and Advance scenario at the Mazam watershed basin as a function of Cumulative frequency have been shows positive changes for most of the frequency values as observed in Figure 7.

4. It is observed from Figure 8 shown for recurrence interval and frequency of a storm that for various magnitude of annual rainfall shows the impact of climate change will more in the advanced scenario in comparison to the base line scenario.

5. It is observed from Figure 9, with increase in rainfall, runoff potential is not noticeable increasing while from Figure 10 shows that runoff generated is less for lower value of rainfall as well as for higher rainfall in Advance scenario and coefficient of correlation is higher in advance scenario as compare with the base scenario.

6. From Figure 13 and Table 1 it is clear that, due to Mazam irrigation project, water storage is more in advance scenario as compare to the base scenario. Due to significant increase in barren land, the runoff reduces due to change in climate change through change in Land use.

7. Result of trend analysis of maximum-minimum temperature, and number of day above the average maximum temperature at both the station shows in Table 4. It is observed from Table 4 that both maximum and minimum temperature reduces in winter season, while they found to be increasing in summer season months

Table 4 Results of trend of minimum-maximum daily temperature and number of day above the maximum average temperature

\begin{tabular}{|c|c|c|c|c|c|c|}
\hline Month & Ambaliyara & & & Modasa & & \\
\hline & $\begin{array}{l}\text { Minimum } \\
\text { Temperature }\end{array}$ & $\begin{array}{l}\text { Minimum } \\
\text { Temperature }\end{array}$ & $\begin{array}{l}\text { No of day } \\
\text { above Max } \\
\text { Average } \\
\text { Temperature }\end{array}$ & $\begin{array}{l}\text { Minimum } \\
\text { Temperature }\end{array}$ & $\begin{array}{l}\text { Minimum } \\
\text { Temperature }\end{array}$ & $\begin{array}{l}\text { No of day } \\
\text { above Max } \\
\text { Average } \\
\text { Temperature }\end{array}$ \\
\hline January & Decreasing & Decreasing & Decreasing & Decreasing & Decreasing & Decreasing \\
\hline February & Decreasing & Increasing & Decreasing & Decreasing & Decreasing & Decreasing \\
\hline March & Decreasing & - & Decreasing & Decreasing & Decreasing & Increasing \\
\hline April & Increasing & Decreasing & Decreasing & Increasing & Decreasing & Decreasing \\
\hline May & Increasing & Increasing & Increasing & Increasing & Increasing & Increasing \\
\hline June & Increasing & Increasing & Increasing & Increasing & Increasing & Increasing \\
\hline July & Increasing & Increasing & Increasing & Increasing & Increasing & Increasing \\
\hline August & Decreasing & - & Increasing & Decreasing & Increasing & Decreasing \\
\hline September & Decreasing & Decreasing & Decreasing & Decreasing & Decreasing & Decreasing \\
\hline October & Decreasing & Decreasing & Decreasing & Decreasing & Decreasing & Decreasing \\
\hline November & Decreasing & Decreasing & Decreasing & Decreasing & Decreasing & Decreasing \\
\hline December & Increasing & Decreasing & Decreasing & Increasing & Decreasing & Decreasing \\
\hline
\end{tabular}




\section{Conclusion}

The Mazam river basin area is 955.98 sq.km covering the catchment. The objective of this study is to investigate the regional impact of climate change on a Mazam river watershed in Sabarmati river basin. The climate change impact on the rainfall and consequently on the runoff in the basin directly influences the whole Sabarmati basin. From results obtained from this study, it is concluded for the study area in the basin as a whole as shown below.

Magnitude of annual rainfall shows increasing trend in a study area with 20-40\%, while number of rainy days in a year also shows decreasing trend, trend of highest Rainfall per day in a year also shows increasing trend. This is indicative intensive rainfall occurring monsoon span resulting from impact of the changing climate.

Number of rainy days in the month of June shows decreasing trend in a study area. This is indicative for the study area that monsoon season tends to start late in the month of June, because both magnitude of rainfall and number of rainy days in the month of June have been reduced.

Magnitude of rainfall and number of rainy days tends to increase in the month of September and October in the study area. This is again indicative of tendency of late vanishing, ceasing of the monsoon season.

Based on the Mann-Kendall test, change in magnitude of slope of trend in the month of July is $+32 \%$, in the month August and September it is found to be change is $+14 \%$, and $+56 \%$ respectively.

Further, it is concluded from the results that for any recurrence interval and frequency of annual rainfall, the magnitude of rainfall increases in advance scenario in comparison to the base line scenario.

Significant increase in barren land, runoff potential reduces for entire range of the rainfall due to change in climate change through change in Land use pattern in advance scenario as compare to the base scenario.

Based on the summary of the trend analysis of daily rainfall in different ranges for each month, it is found that moderate rainfall increases in all the months, rather heavy rainfall increases in all the months except month of October and heavy and very heavy rainfall increases in month of July and September.

Maximum and minimum temperature in the basin, in winter months reduces, while in summer monsoon season it shows increasing trend in both the case. This is indicative of extreme weather in climate change/advance scenario

It is summarized that the climate change impacts on the small-regional scale study area confirms the increase in the annual rainfall magnitude increase in the intense rainfall in the month of July and August, and shifting of the monsoon season to start and finish late. 
The outcomes of climatic study will be beneficial for the regional methodical and international systematic communities for articulating appropriate policies in order to mitigate adversative impacts of changing climate in the arid regions of this study area and other parts in the world.

\section{Acknowledgements}

Authors are thankful to the Climate change department and Higher Education Department for funding the climate change project, under which this study is carried out. Also, the authors are thankful to the State Water Data Centre (SWDC), Gandhinagar for providing the necessary data. The authors are thankful to the authority of Maharaja Sayajirao University of Baroda, Vadodara, where this study is continued.

\section{Conclusion}

According to the combined data of GSM outputs, temperature and precipitation are on the rise in Chabahar Station. The temperature is reported $26.2^{\circ} \mathrm{C}$ in the base observational period. According to the models, the temperatures are $26.72,27.62$, and $28.58^{\circ} \mathrm{C}$ in $2011-2030,2040-2060$, and 20802099. On the average, 0.52-2.38 increase is seen. In terms of precipitation, it experiences a rising pattern. Precipitation is reported $57 \mathrm{~mm}$ in the base period. Chabahar suffers from unpleasant conditions in all months using the bioclimatic indicators. In other words, it is constantly in warning list for human health and urban and rural ecosystem. This is a warning alarm for politicians and planners.

\section{References}

Anderson, G.B., and Bell, M.L., 2011, Heat waves in the United States: mortality risk during heat waves and effect modification by heat wave characteristics in 43 U.S. communities, Environmental Health Perspectives, 119(2),1552-9924.

Ashofteh, P.S., Massah-Bavani, A.R., 2012, Investigation of AOGCM Model Uncertainty and Emission Scenarios of Greenhouse Gases Impact on the Basin Runoff under Climate Change, Case study Gharanghu Basin, East Azerbaijan, Iran-Water resources research, 8 (2):36-47 .

Babaian, I., and Najafi Nik Z., 2006, Introducing and Evaluation of LARS-WG Model for Modeling Meteorological Parameters of Khorasan Province (1961-2003), Nivar Journal. 62(63):69-49 .

Boumans, R.J.M., Phillips, D.L., Victery, W., Fontaine, T.D., 2014, Developing a model for effects of climate change on human health and health-environment interactions: Heat stress in Austin, Texas. Urban Climate. 8:78-99.

Blazejczyk, M., 2001, Help of Biokima for window. Version 2.6.

Committee on Climate; Ecosystems; Infectious Diseases; and Human Health; Board on Atmospheric Sciences and Climate; Commission on Geosciences EaRDoEaLSN. 2001, The under weather: Climate, Ecosystems, and Infectious Disease. Washington, D.C.: National Academy Press.

Darand, M., 2014, Recognition and spatial-temporal analysis of heat waves in Iran. Geography and development Iranian Journal. 12(35),167-80 .

Dargahian, F., and Rezaie, Gh.H., 2014., Study of synoptic and bioclimatology conditions of heat index using geographic information system at coastal and see station, in south of country and its effects on human health. Geographical Data. 23(91),43-54. 
Esmaeilnegad, M., khosravei, M., Aliganei, B., and masoodeian, S.A., 2014, Identifying Heat Waves of Iran. Geography and development Iranian Journal,11(33):39-54.

Greene, L., Kalkstein, L., Mills, D.J.S., 2011, An Examination of Climate Change on Extreme Heat Events and Climate-Mortality Relationships in Large U.S. Cities, American Meteorological Society, 3(4),281-92.

Giannakopoulos, C., Psiloglou, B., Lemesios, G., Xevgenos, D., Papadaskalopoulou, C., Karali, A., Varotsos, K.V., Zachariou-Dodou, M., Moustakas, K., Ioannou, K., Petrakis, M., and Loizidou, M.,2016, Climate change impacts, vulnerability and adaptive capacity of the electrical energy sectorin Cyprus. Regional Environmental Change, 16(7),1891-904.

Glaser, J., Lemery, J., Rajagopalan, B., Diaz, H.F., García-Trabanino, R., Taduri, G., Madero, M., Amarasinghe, M., Abraham, G., Anutrakulchai, S., Jha, V., Stenvinkel, P., Roncal-Jimenez, C., Lanaspa, M.A., Correa-Rotter, R., Sheikh-Hamad, D., Burdmann, E.A., Andres-Hernando, A., Milagres, T., Weiss, I., Kanbay, M., Wesseling, C., Sánchez-Lozada, L.G., and Johnson, R.J., 2016, Climate Change and the Emergent Epidemic of CKD from Heat Stress in Rural Communities: The Case for Heat Stress Nephropathy. Clinical Journal of the American Society of Nephrology, 11(8):1472-83.

Hamidian Pour, M., Baaghideh M, and Abbas Nia, M., 2016, Assessment of the Precipitation and Temperature Changes over South East Iran Using Downscaling Of General Circulation Models Outputs, Physical Geography Research Quarterly, 48(1),107-23.

Jeremy, S. Pal and Elfatih, A.B. Eltahir, 2015, Future temperature in south west Asia projected to exceed a threshold for human adaptability, Nature Climate Change, 6, 197-200, DOI: 10.1038/NCLIMATE2833. www.nature.com/natureclimatechange.

IPCC, 2007, Climate change 2007-the physical science basis: Working group I contribution to the fourth assessment report of the IPCC. Cambridge, United Kingdom and New York, NY, USA.: Cambridge University Press.

IPCC, 2013, The Physical Science Basis. Working Group I Contribution to the Fifth Assessment Report of the Intergovernmental Panel on Climate Change. First published 2013 ed. Cambridge, United Kingdom and New York, NY, USA,: Cambridge University Press.

Knowlton, K., Rotkin-Ellman, M., King, G., Margolis, H.G., Smith, D., Solomon, G., Trent, R., and English, P., 2009, The 2006 California heat wave: impacts on hospitalizations and emergency department visits. Environmental Health Perspect, 117(1): 61-67.

Lundgren, K., Kuklane, K., Cao, C., and Holmér, I., 2013, Effects of heat stress on working populations when facing climate change .Industrial Health, 51(1):3-15.

Massah-Bavani, A.R., and Morid, S., 2006, Impact of Climate Change on the Water Resources of Zayandeh Rud Basin. Journal of Science and Technology of Agriculture and Natural Resources, 9(4),17-28.

Massah-Bavani, A.R., and Morid, S., 2005, Impact of climate change on water resources and agriculture, Iran-eater resources research, 1(1),40-47.

Nematchoua, M.K., Roshan Gh. R., and Tchinda, R., 2014, Impact of Climate Change on Outdoor Thermal Comfort and Health in Tropical Wet and Hot Zone (Douala), Cameroon. Iranian Journal of Health Sciences, 2(2),25-36.

Nian-Zhi, J., Da-Ke, C., Yong-Ming, L., Xiao-Ping, H., Rui, Z., Hai-Bo, Z., Zhi-Jian, J., and Fei, Z., 2015, Climate change and anthropogenic impacts on marine ecosystems and countermeasures in China. Advances in Climate Change Research, 6(2 ):118-125. 
Reid, C.E., Neil, S.O.M., Gronlund, J.C., Brines, J.S., Brown, G.D., Diez-Roux, V.A. and Schwartz, J., 2009, Mapping community determinants of heat vulnerability, Environmental. Health Perspectives, 117(11):1730-36.

Roshan, Gh.R., Khoshakhlagh, F., and Azizi, Gh., 2012. Assessment of Suitable General Atmosphere Circulation Models for Forecasting Temperature and Precipitation Amounts in Iran Under Condition of Global Warming. Geography and development Iranian Journal, 10(27), 19-36 .

Semenov, M.A., and Barrow, E.M., 2002, Lars-WG a stochastic weather generator for use in climate impact studies. User's manual, Version3.0.

Smith KRA, Woodward D, Campbell-Lendrum DD, Chadee Y, Honda Q, Liu JM, et al. Human health: impacts, adaptation, and co-benefits. In: Climate Change 2014: Impacts, Adaptation, and Vulnerability. Part A: Global and Sectoral Aspects. Contribution of Working Group II to the Fifth Assessment Report of the Intergovernmental Panel on Climate Change. Cambridge, United Kingdom and New York, NY, USA.: Cambridge University Press; 2014.

Tavousi, T., Khosravi, M., and Hosseinabady, N., 2013, Monsoon Systems Impact in the Exacerbation of Malaria in Southern Sistan and Baluchestan Province with Emphasis on Chabahar city. GEOGRAPHY AND ENVIRONMENTAL HAZARDS, 7(2): 5-8.

Turleya, M.C., and Ford, D.E., (2009) Definition and calculation of uncertainty in ecological process models. Ecological Modelling. Volume 220, Issue 17, 10 September 2009, Pages 1968-1983.

Wilby, R.L., and Dessai, S., 2010, Robust adaptation to climate change, Journal Weather, 65(7), 18018;65(7):180-18. DOI: 10.1002/wea.543. 